\title{
Local ranges of phytosociological associations: are they reflected in numerical classification?
}

\author{
Ilona Knollová, Milan Chytrý, Lubomír TichÝ \& Ondřej HÁJEK \\ Department of Botany, Masaryk University, Kotlářská 2, CZ-61137 Brno, Czech Republic; e-mail: ikuzel@sci.muni.cz, \\ chytry@sci.muni.cz,tichy@sci.muni.cz,ohajek@sci.muni.cz.
}

\begin{abstract}
In the tradition of European phytosociology, delimitations of vegetation units such as associations are mostly based on data from small areas where more detailed vegetation sampling has been carried out. Such locally delimited vegetation units are often accepted in large-scale synthetic classifications, e.g. national vegetation monographs, and tentatively assigned to a small geographical range, forming groups of similar (vicarious) vegetation units in different small areas. These vicarious units, however, often overlap in species composition and are difficult to recognize from each other. We demonstrate this issue using an example of the classification of dry grasslands (Festuco-Brometea) in the Czech Republic. The standard vegetation classification of the Czech Republic supposes that the majority of accepted associations (66 out of 68) have a restricted distribution in one of the two major regions, Bohemia or Moravia. We compared the classification into traditional associations with the numerical classification of 1440 phytosociological relevés from the Czech Republic, in order to test whether the traditionally recognized associations with small geographical ranges are reflected in numerical classification. In various comparisons, the groups of relevés identified by numerical analysis occupied larger areas than the traditional associations. This suggests that with consistent use of total species composition as the vegetation classification criterion, the resulting classification will usually include more vegetation units with larger geographical ranges, while many of the traditional local associations will disappear.
\end{abstract}

Key words: dry grasslands, ecological scale, vegetation survey

\section{Introduction}

Most studies focusing on vegetation classification have been carried out in local areas, for example in a single mountain range or a single valley. In many of these studies, vegetation syntaxa of the BRAUn-BLANQUET system were newly delimited and formally described without sufficient comparison with similar syntaxa already described by other authors in other areas. In such a way, many local associations have been described, but without a detailed analysis of the data from a large area, the degree of overlap among them remains unclear. In national overviews of plant associations that are based on a review of the literature rather than the analysis of primary data (e.g. MuCINA et al., 1993; Moravec et al., 1995; Pott, 1995; MAtuszkiEwicz, 2001; ScHUBERT et al., 2001), putative boundaries between the geographical ranges of such associations are often drawn artificially, e.g. along the boundaries between contrasting geological formations or topographical features. However, if relevé data sets from larger areas are analysed with numerical classification techniques (e.g. RoDWELL et al., 1990-2000; SCHAMINÉE et al., 1995-1999; VAlaChOviČ et al., 1995 et seq.; BERG et al., 2001-2004), different patterns often emerge. Differences in species composition of vegetation units between local areas may appear to be smaller than as previously thought based on the expert judgement. Often, local differences within traditional associations, e.g. due to edaphic variation, are found to be larger than the differences between vegetation growing in different areas and traditionally assigned to different associations. The detection of such a pattern would support the lumping of local associations. By contrast, revealing distinct differences in species composition between different areas would support the concept of local associations.

A more complex pattern appears when in some restricted patches within area A local vegetation is more similar to the prevailing vegetation of area $\mathrm{B}$ than to the prevailing vegetation of area A. An example is a southern vegetation type confined to the driest and warmest habitats of south-facing slopes at high latitudes of the northern hemisphere. This phenomenon has since long been recognized in plant ecology and biogeography as the "rule of relative habitat constancy" (WALTER \& WALTER, 1953). In spite of the wide acceptance of this rule in European phytogeography, we hypothesize that it is not adequately reflected 
in many of the existing phytosociological classification systems. These classification systems tend to assume crisp geographical boundaries between similar associations, which imply that each local area harbours a single association from a group of several vicarious associations and these associations hardly overlap in their geographical ranges. KNolloví \& CHYTRÝ (2004) analysed and discussed one of the many examples of such classifications, Central European oak-hornbeam forests (NEuHÄUsL, 1977).

The aim of the present paper is to demonstrate the deviance in the geographical delimitation of the traditional phytosociological syntaxa and vegetation units established using more formalized classification methods. We use an example of the classification of dry grassland vegetation, belonging to the phytosociological class of Festuco-Brometea, in the Czech Republic. Dry grasslands have a disjunctive distribution in the Czech Republic, being distributed in two areas of dry and warm climate, which are separated by unsuitable cool and wet areas (CHYTRÝ et al., 2001). In the national phytogeographical land classification (SKALICKÝ, 1988), these two dry and warm areas are called the Bohemian Thermophyticum (including central, northern and eastern Bohemia) and the Pannonian Thermophyticum (including southern Moravia). For convenience, we will refer to Bohemia and Moravia, respectively, throughout this paper.

As a species-rich vegetation type, Czech dry grasslands have always attracted botanists. The first phytosociological studies of this vegetation date back to the 1920s/ 1930s (ZlatníK, 1928; KLIKA, 1931, 1933). However, individual phytosociological studies of dry grasslands have always been restricted to either Bohemia (e.g. KolBEK, 1975, 1978, 1979; STUDNičKA, 1980; TOMAN, 1981, 1988) or Moravia (VICHEREK \& UnAR, 1971; Chytrý \& VichereK, 1996; ChytrÝ et al., 1997; TICHÝ et al., 1997), which resulted in different associations being described in these regions. Of the total number of 68 associations of the FestucoBrometea class listed in the national synopsis (KOLBEK in MorAVEc et al., 1995), only two are reported to occur both in Bohemia and Moravia. It is true that the dry grasslands of Bohemia and Moravia are different to some degree, as the warm and dry area of Bohemia is entirely surrounded by mountains whereas southern Moravia has been always open to the migrations of continental steppe flora from the Pannonian region of Hungary, southern Slovakia and eastern Austria. However, the question is whether the degree of difference between these two warm and dry areas is really so large that 66 of 68 plant associations can be considered as occurring in just one of them.

In this paper, we use the national data set of dry grassland relevés to test whether the geographical ranges of plant associations delimited in the phytosociological literature are more restricted than comparable vegetation units derived from numerical classification.

\section{Material and methods}

Data set

The basic data set for the analysis included 6221 georeferenced vegetation plots (relevés) of dry grasslands of the phytosociological class Festuco-Brometea from the Czech National Phytosociological Database (www.sci.muni.cz/ botany/database.htm, CHYTRÝ \& RAFAJOVÁ, 2003). Relevés from plots of the size $<4 \mathrm{~m}^{2}$ or $>100 \mathrm{~m}^{2}$ were deleted. Relevés were assigned to the associations according to KOLBEK (in MORAVEC et al., 1995) and more recent papers with descriptions of new associations from the Czech Republic (CHYTRÝ \& ViCHEREK, 1996; ChytrÝ et al., 1997; TICHY et al., 1997). The association assignments were made according to the original authors of the relevés; the relevés that had not been assigned to the associations were removed from the data set. To reduce over-sampling of some areas, the data set was geographically stratified in the JUICE program (TICHÝ, 2002). Only one relevé from each association was selected from each cell of a geographical grid of 0.75 latitudinal $\times 1.25$ longitudinal minutes, i.e. approximately 1.5 $\times 1.5 \mathrm{~km}$. If a cell contained more than one relevé belonging to the same association, the relevés with a less accurate locality indication were removed first and of the remaining relevés, one was selected at random. The resulting data set contained 1440 relevés. For the analysis, we deleted all records of bryophytes and lichens, as these were not recorded in all relevés, and the records of trees and shrubs (including juveniles), which seldom occurred in the relevés.

\section{Classification}

Two classifications of the data set of 1440 relevés were prepared: classification into traditional phytosociological associations and numerical classification. In the former, 71 associations were recognized, taking over the association assignments according to the authors of the relevés. Of these, 66 associations were from the national overview (KOLBEK in MORAVEC et al., 1995; relevés were available for 66 from the total number of 68 associations) and 5 associations were added, as they were not included in the national overview.

Numerical classification was prepared with cluster analysis, using the $\beta$-flexible group linkage method with $\beta=-0.20$ and relative Euclidean (chord) distance as a measure of the dissimilarity in floristic composition between relevés (PC-ORD program; MCCUNE \& MEFFORD, 1999). Species covers, originally recorded on Braun-Blanquet or Domin scale, were converted into mid percentage values of each degree on these scales and square-root transformed. As the aim was to compare the classification into phytosociological associations with the numerical classification, 71 groups, i.e. the same number as the number of associations present in the Czech National Phytosociological Database, were accepted from higher hierarchical levels of the cluster analysis dendrogram.

\section{Measuring geographical range size}

The geographical range sizes of the communities (associations or groups resulting from cluster analysis) within the country were compared using different methods, which reflect different facets of the range size and area occupancy within the range:

1. The number of occupied phytogeographical districts. The phytogeographical land classification of SKALICKY (1988) was used, which divides the area of the Czech Republic into 99 phytogeographical districts, each harbouring 
a

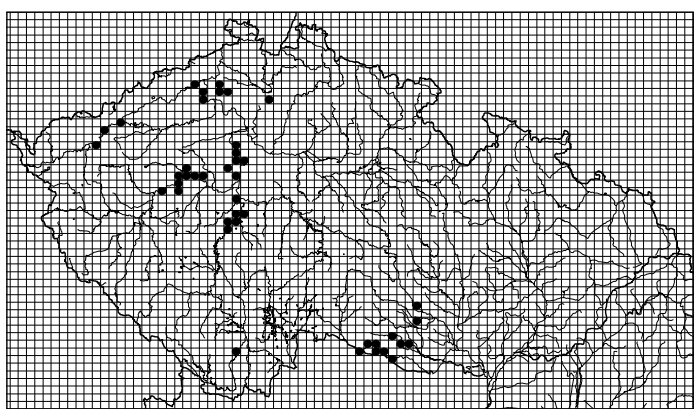

C

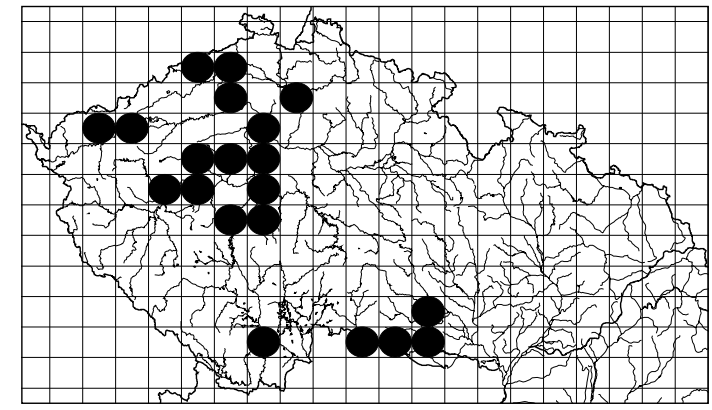

e

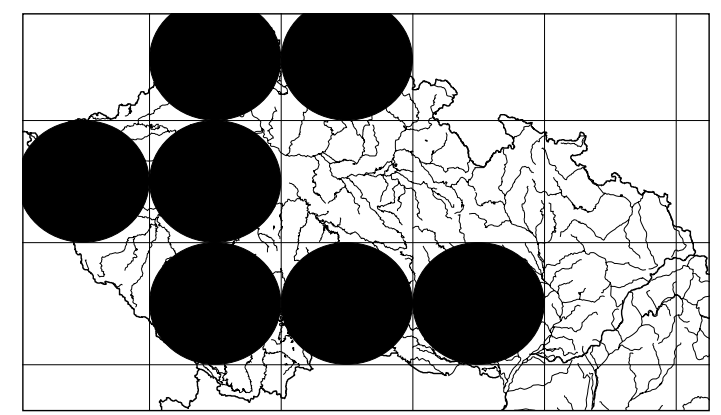

b

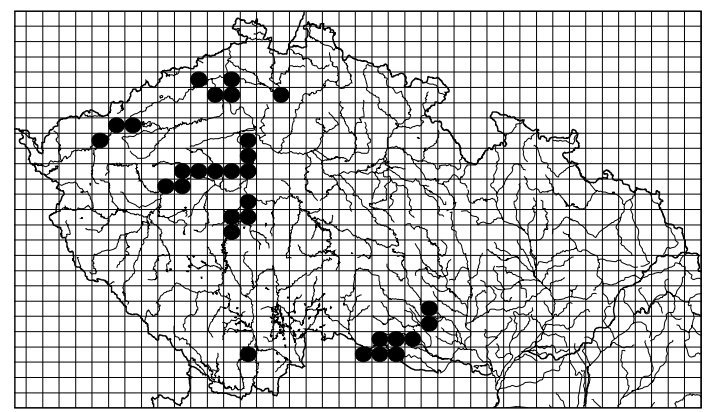

$\mathrm{d}$

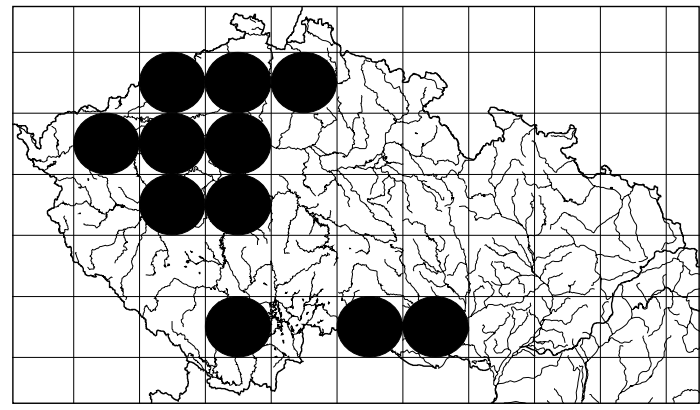

f

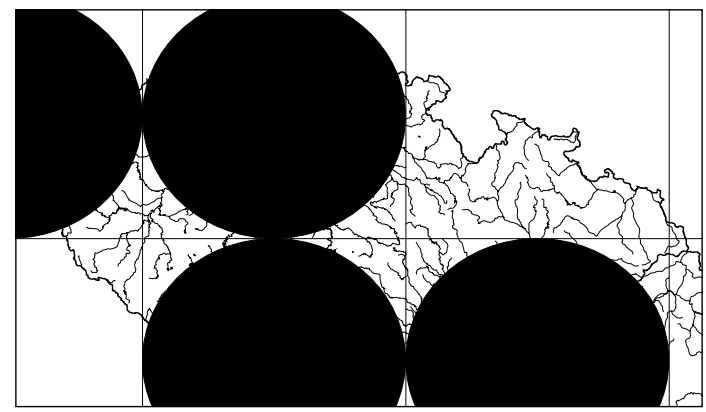

Fig. 1. Changing numbers of occupied cells with decreasing resolution of the geographical grid: an example for a selected vegetation unit. a) 3 latitudinal $\times 5$ longitudinal minutes; b) $6 \times 10^{\prime}$; c) $12 \times 20^{\prime}$; d) $24 \times 40^{\prime}$; e) $48 \times 80^{\prime}$; f) $96 \times 160^{\prime}$.

relatively homogeneous flora and vegetation that is different from the neighbouring districts.

2. The number of occupied cells of geographical grids. The national territory was divided by geographical grids with cells of increasing size (Fig. 1).

3. Mean geographical distance between all pairs of relevés belonging to the same community. In the ArcGIS 8.3 geographical information system (www.esri.com) the geographical coordinates of relevés were recalculated from polar coordinates of the WGS 84 system into plain coordinates of the national system JTSK and subsequently the distances between sites were calculated. The median of the distances was used to characterize the geographical range size of each community within the country.

4. The area occupied by each community, identified from the position of the border sites. The border sites were identified within ArcGIS 8.3 by the script Convex Hull/Convex Envelope (http://arcscripts.esri.com/ details.asp?dbid=12084), which creates the convex envelope (minimum bounding) of a set of points. Subsequently the area bounded by the envelope was calculated.

Geographical range sizes, identified by each of the above measures, were compared between the phytosociological associations and groups delimited by cluster anal- ysis. The differences were tested using the nonparametric MANN-WHitNeY U test, as available in the STATISTICA 7.0 program (www.statsoft.com).

\section{Results}

Fig. 2 shows that according to the standard national list of plant associations, (KOLBEK in MORAVEC et al., 1995) 44 traditional associations only occur in Bohemia, 22 only in Moravia and just two associations in both areas. The respective figures with the five added associations are 44-27-2. The authors of the relevés contained in the national phytosociological database mostly used the same associations as included in the national list; however, they tended to assign some Bohemian relevés to the "Moravian associations" and vice versa. Still, the collective opinion of Czech vegetation scientists, represented by the association assignments made by different authors, assumed that just 13 of the 71 associations occur in both areas. Cluster analysis resulted in a contrasting pattern: more than half of the relevé clusters (37 of 71) occurred in both areas. 


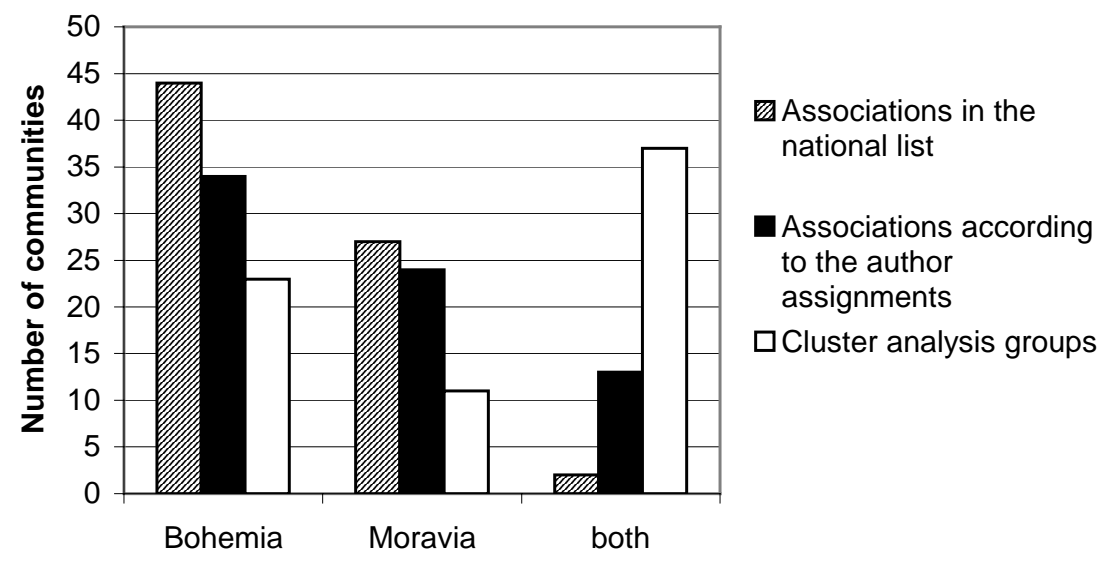

Fig. 2. Number of communities occurring only in Bohemia, only in Moravia, or in both of these areas according to the national list (Kolbek in Moravec et al., 1995). Communities are either the traditional phytosociological associations or groups defined by cluster analysis.

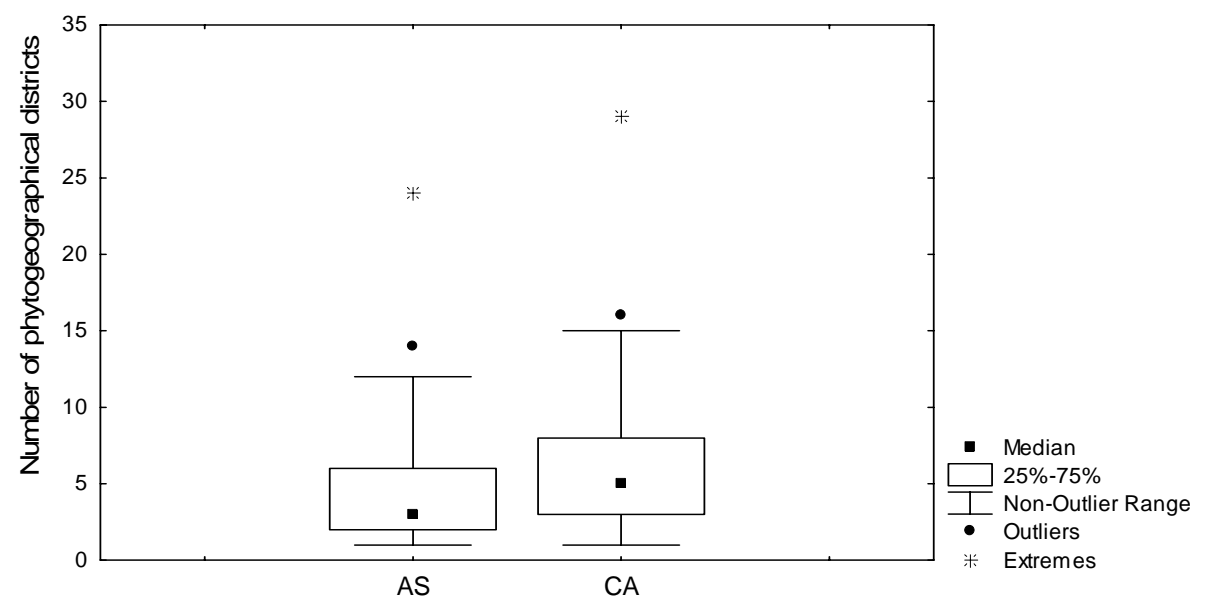

Fig. 3. The numbers of occupied phytogeographical districts for 71 communities. AS - associations, CA groups from cluster analysis. The differences are significant at $P<0.05$ (MANN-Whitney U test).
Table 1. Cell sizes in geographical grids and the significances (MANN-WHitney U test) of differences in the total number of occupied cells between associations and groups defined by the cluster analysis.

\begin{tabular}{ccc}
\hline Latitude $\times$ longitude $\left(^{\prime}\right)$ & $\mathrm{km} \times \mathrm{km}$ & Difference \\
\hline $0.75 \times 1.25$ & $1.5 \times 1.5$ & n. s. \\
$1.5 \times 2.5$ & $3 \times 3$ & n. s. \\
$3 \times 5$ & $6 \times 6$ & n. s. \\
$6 \times 10$ & $12 \times 12$ & n. s. \\
$12 \times 20$ & $24 \times 24$ & $P<0.05$ \\
$24 \times 40$ & $48 \times 48$ & $P<0.01$ \\
$48 \times 80$ & $96 \times 96$ & $P<0.01$ \\
$96 \times 160$ & $192 \times 192$ & $P<0.01$ \\
$192 \times 320$ & $384 \times 384$ & $P<0.01$ \\
\hline
\end{tabular}

The median number of occupied phytogeographical districts was 3 for associations and 5 for groups from cluster analysis. This difference was significant (MANNWhitney U test, $P<0.05$, Fig. 3).

The differences in the numbers of occupied cells within geographical grids between associations and the groups resulting from cluster analysis were significant with cell sizes of $24 \times 24 \mathrm{~km}$ and larger (Tab. 1, Fig. 4).

The geographical distances between relevés assigned to the same association were significantly smaller than the distances between relevés belonging to the same group of the cluster analysis (MANN-WHITNEY $\mathrm{U}$ test, $P<0.05$, Fig. 5). This means that on average the relevés belonging to the same association were located closer together than relevés belonging to the same group of cluster analysis. Similarly, the area delimited by the border relevés was significantly smaller for associations than for the groups of cluster analysis (Mann-Whitney U test, $P<0.05$, Fig. 6).

\section{Discussion}

All the methods used for comparison of the geographical range size within the national territory showed that the traditional phytosociological associations tended to have a smaller distribution range than the groups resulting from cluster analysis. This result indicates that traditional phytosociology tends to consider associations as having smaller distributions than would be suggested by the consistent application of numerical classification methods. It must be noted that numerical analysis includes different methods whose results may differ; however, our pilot analyses that are not shown in this paper gave very similar results to the one presented. Therefore we believe that the main difference is between the traditional and numerical methods. We suggest the following explanations for this difference: 


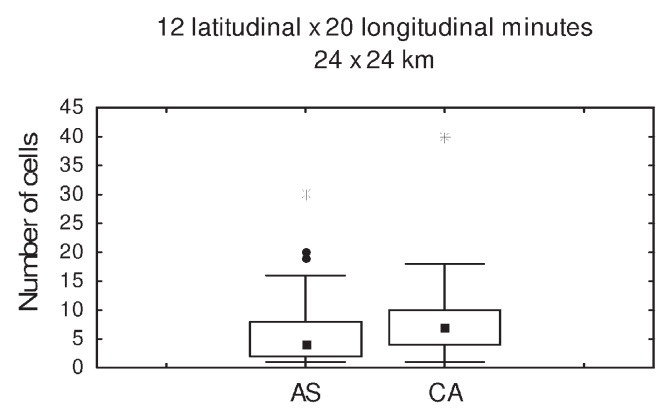

48 latitudinal $\times 80$ longitudinal minutes $96 \times 96 \mathrm{~km}$

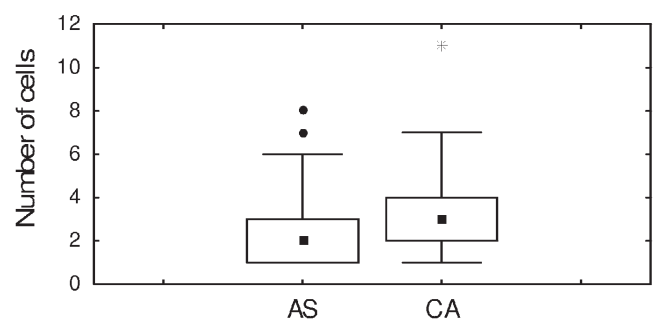

24 latitudinal $\times 40$ longitudinal minutes $48 \times 48 \mathrm{~km}$

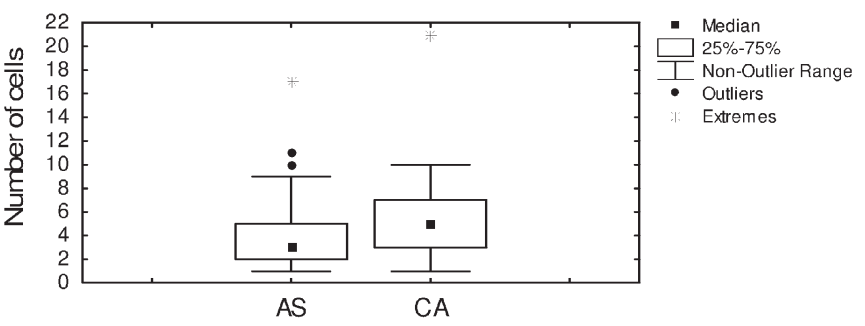

96 latitudinal $\times 160$ longitudinal minutes $192 \times 192 \mathrm{~km}$

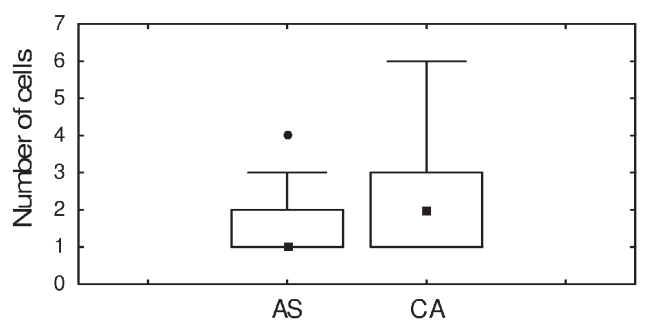

Fig. 4. The numbers of occupied cells in geographical grids with different resolutions. AS - associations, CA - groups from cluster analysis. The differences are significant at $P<0.05$ (Mann-Whitney U test); plots for smaller cells, where the differences were not significant, are not shown (see Tab. 1).
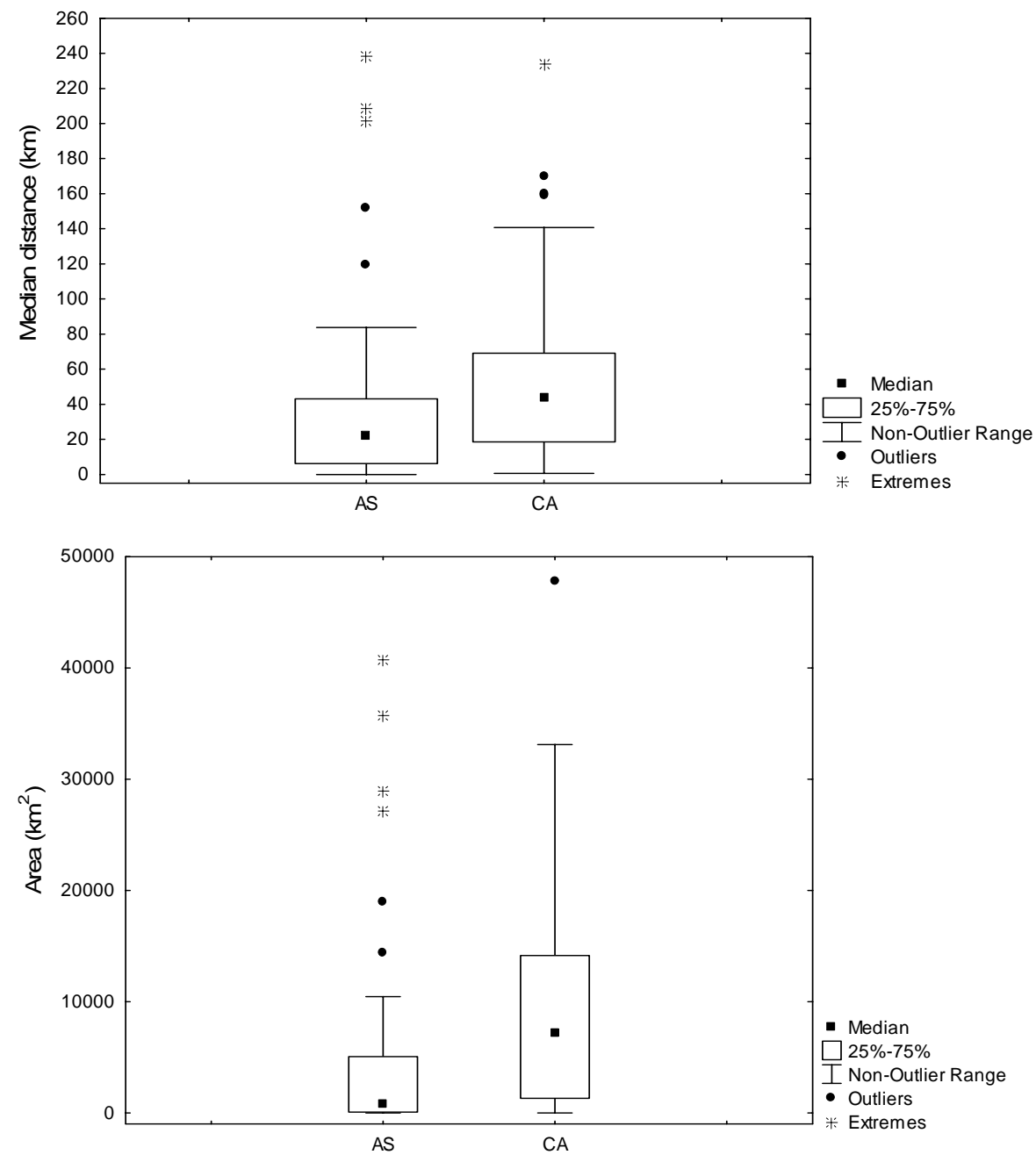

Fig. 5. The median distances between localities. AS - associations, CA groups from cluster analysis. The difference is significant at $P<0.05$ (MANN-Whitney U test).
Fig. 6. The area occupied by the individual communities. AS - associations, $\mathrm{CA}-$ groups from cluster analysis. The differences are significant at $P<0.05$ (MANNWhitNey U test). 
(1) The relationships between traditional associations described in local studies are insufficiently analysed in large-scale overviews of vegetation units. Detailed comparisons of similar vegetation units between different areas are often not performed and local associations are simply taken over and hypothetical geographical boundaries between them are delineated using an expert guess. Such an approach has a long tradition and was sometimes also explicitly applied in the phytosociological terminology (e.g. "territorial associations" vs. "main associations"; KNAPP, 1948).

(2) Traditional subjective classification often uses habitat characteristics as an auxiliary classification criterion, in addition to the floristic criteria. In such a way, very similar plant communities on different bedrocks can be assigned to different associations, in spite of the fact that numerical classification based solely on floristic criteria would not find much difference between them and merge them in a single cluster. As the habitat characteristics are often spatially auto-correlated, their inclusion among classification criteria probably tends to produce more local associations than communities entirely based on floristic composition. A strong emphasis on non-floristic classification criteria is explicitly admitted in classifications made for forestry purposes (e.g. ElleNBERG \& KLÖTZLI, 1972); however, the attitude of the followers of the BRAUN-BLANQUET approach to the use of these criteria seems to be rather confusing. In his early theoretical paper, BRAUN-BLANQUET (1921) postulated that floristic criteria are superior for the classification, as habitat characteristics can be indicated through floristic composition. However, it is obvious that many phytosociologists did not follow this requirement, although they usually did not admit it explicitly, perhaps except for their use of physiognomic criteria (WESTHOFF, 1967).

(3) Traditional classification involves different weighting of species in the classification process, whereas numerical classification usually uses all species as classification criteria and treats them as being equal. It seems to be common that the traditional classification approach gives a higher weight to geographically restricted species, which results in delimitation of local associations.

The current study uses just one example of the phenomenon of local associations used in traditional phytosociology, which might perhaps be considered as an extreme case that developed due to the specific local tradition of vegetation classification. However, we believe that this phenomenon is widespread in traditional phytosociology. Our example is from a single country with a single tradition of phytosociological research. Looking at the lists of dry grassland associations from countries neighbouring the Czech Republic, we find there is not a single association listed for Germany (Pott, 1995; Schubert et al., 2001) and Poland (MATuszkiewicz, 2001) that would be described from the territory of the Czech Republic. This is surpris- ing, given that the environmental features of dry areas in these countries, as well as their phytogeographical histories, are similar. Also, phytosociological studies of Czech dry grasslands started at the same time as in Germany and Poland: KolbeK (in Moravec et al., 1995) lists 17 dry grassland associations described from the Czech territory before 1940. Thus the local delimitation of the traditional associations is further amplified by different research traditions existing in different countries (BRUELHEIDE \& CHYTRÝ, 2000).

Recent compilations of large electronic databases of phytosociological relevés (EWALD 2001; HENNEKENS \& SChaminÉE, 2001) call for revisions of the traditional vegetation typologies, using geographically wide data sets and formalized classification methods. Numerical classification methods are generally favoured, as they consistently apply the same classification criteria to all the relevés in the data set (GRABHERR et al., 2003; Havlová et al., 2004; KNOllová \& ChytrÝ, 2004; ROLEČEK, 2005), which is mostly not the case in the traditional classification based on expert knowledge. Without any doubt, the legacy of the traditional phytosociology is in need of a profound revision before it is applied in large-scale habitat inventories or nature conservation monitoring programmes. However, it must be kept in mind that vegetation units resulting from the unsupervised numerical classification such as cluster analysis will often be different from the traditional ones. This difference will probably not only result from the higher consistency of the numerical methods; it will also be due to the emphasis of numerical methods on the floristic classification criteria, and absence of species weighting. As the current study shows, one of the differences can be the tendency of vegetation units based on numerical classification to occupy larger geographical ranges. Vegetation units with larger ranges are advantageous for easier communication among vegetation scientists, habitat experts and nature conservationists from different areas. However, there is no theoretical reason to consider the units with large geographical ranges as being objectively better than local vegetation units, because the ranges are as artificial as the vegetation units themselves. Recent developments of supervised methods of vegetation classification (EJRNÆS et al., 2004), which involve species weighting, are able to reproduce some of the traditional vegetation units, including the local ones, much better than cluster analysis and similar unsupervised methods. The Cocktail method (BRUELHEIDE, 2000; KoČí et al., 2003; LososovÁ, 2004) or artificial neural networks (ČERNÁ \& CHYTRÝ, 2005) give promising results in this respect.

\section{Acknowledgements}

We thank Jan ROLEČEK for his comments on a previous version of the manuscript. This study was supported by the grants GA ČR 206/05/0020 (M. C., L. T. and O. H.), GA AV ČR KJB601630504 (I. K.) and the institutional long-term research plan MSM 0021622416. 


\section{References}

Berg, C., Dengler, J., Abdank, A. \& Isermann, M. (eds) 2004. Die Pflanzengesellschaften Mecklenburg-Vorpommerns und ihre Gefährdung - Textband. Weissdorn-Verlag, Jena. $606 \mathrm{pp}$.

Braun-Blanquet, J. 1921. Prinzipien einer Systematik der Pflanzengesellschaften auf floristischer Grundlage. Jahrb. St. Gallischer Naturwiss. Ges. 57: 305-351.

Bruelheide, H. 2000. A new measure of fidelity and its application to defining species groups. J. Veg. Sci. 11: 167-178.

Bruelheide, H. \& Chytrý, M. 2000. Towards unification of national vegetation classifications: comparison of two methods for analysis of large data sets. J. Veg. Sci. 11: 295-306.

Černá, L. \& Chytrý, M. 2005. Supervised classification of plant communities with artificial neural networks. J. Veg. Sci. 16: 407-414.

Chytrý, M., KuČera, T. \& KoČí, M. (eds) 2001. Katalog biotopů Ceské republiky. Agentura ochrany př́rody a krajiny ČR, Praha, 304 pp.

Chytrý, M., Mucina, L., Vicherek, J., Pokorny-Strudl, M., Strudl, M., Koo, A. J. \& MaglockÝ, Š. 1997. Die Pflanzengesellschaften der westpannonischen Zwergstrauchheiden und azidophilen Trockenrasen. Diss. Bot. 227: 1-116.

Chytrý, M. \& Rafajová, M. 2003. Czech National Phytosociological Database: basic statistics of the available vegetationplot data. Preslia 75: 1-15.

Chytrý, M. \& Vicherek, J. 1996. Přirozená a polopřirozená vegetace údolí řek Oslavy, Jihlavy a Rokytné. Př́rod. Sborn. Západomorav. Muz. Třebíč. 22: 1-125.

Ejrnæs, R., Bruun, H.H., Aude, E. \& Buchwald, E. 2004. Developing a classifier for the Habitats Directive grassland types in Denmark using species lists for prediction. Appl. Veg. Sci. 7: 71-80.

EllenberG, H. \& KlÖtzli, F. 1972. Waldgesellschaften und Waldstandorte der Schweiz. Mitt. Schweiz. Anst. Forstl. Versuchsw. 48: 593-930.

EwALD, J. 2001. Der Beitrag pflanzensoziologischer Datenbanken zur vegetationsökologischen Forschung. Ber. Reinhold-TüxenGes. 13: 53-69.

Grabherr, G., Reiter, K. \& Willner, W. 2003. Towards objectivity in vegetation classification: the example of the Austrian forests. Plant Ecol. 169: 21-34.

Havlová, M., Chytrý, M. \& Tichý, L. 2004. Diversity of hay meadows in the Czech Republic: major types and environmental gradients. Phytocoenologia 34: 551-567.

Hennekens, S.M. \& Schaminée, J.H.J. 2001. TURBOVEG, a comprehensive data base management system for vegetation data. J. Veg. Sci. 12: 589-591.

KLIKA, J. 1931. Studien über die xerotherme Vegetation Mitteleuropas I. Die Pollauer Berge im südlichen Mähren. Beih. Bot. Cbl. 47 B: 343-398.

KLIKA, J. 1933. Studien über die xerotherme Vegetation Mitteleuropas II. Xerotherme Gesellschaften in Böhmen. Beih. Bot. Cbl. 50 B: 707-773.

KNAPP, R. 1948. Einführung in die Pflanzensoziologie. Heft 1: Arbeitsmethoden der Pflanzensoziologie und die Eigenschaften der Pflanzengesellschaften. Ulmer, Stuttgart. 100 pp.

Knollová, I. \& Chytrý, M. 2004. Oak-hornbeam forests of the Czech Republic: geographical and ecological approaches to vegetation classification. Preslia 76: 291-311.

Kočí, M., Chytrý, M. \& Tichý, L. 2003. Formalized reproduction of an expert-based phytosociological classification: A case study of subalpine tall-forb vegetation. J. Veg. Sci. 14: 601-610.

Kolbek, J. 1975. Die Festucetalia valesiacae-Gesellschaften im Ostteil des Gebirges České středohoří (Böhmisches Mittelgebirge) 1. Die Pflanzengesellschaften. Folia Geobot. Phytotax. 10: $1-57$.
KolbeK, J. 1978. Die Festucetalia valesiacae-Gesellschaften im Ostteil des Gebirges České středohoří (Böhmisches Mittelgebirge) 2. Synökologie, Sukzession und syntaxonomische Ergänzungen. Folia Geobot. Phytotax. 13: 235-303.

KolbEK, J. 1979. Společenstva řádu Festucetalia valesiacae v Čechách. Syntaxonomická revize. Ms., thesis, Institute of Botany, Průhonice.

LososovÁ, Z. 2004. Weed vegetation in southern Moravia (Czech Republic): a formalized phytosociological classification. Preslia 76: $65-85$.

Matuszkiewicz, W. 2001. Przewodnik do oznaczania zbiorowisk roślinnych Polski. Wydawnictvo naukowe PWN, Warszawa. 537 pp.

McCune, B. \& Mefford, M.J. 1999. PC-ORD. Multivariate analysis of ecological data. Version 4. MjM Software Design, Gleneden Beach. 237 pp.

Moravec, J., Balátová-Tuláčková, E., Blažková, D., Hadač, E., Hejný, S., Husák, Š., Jeník, J., Kolbek, J., Krahulec, F., KropÁC, Z., Neuhäusl, R., RybníČeK, K., ŘEHOŘEK, V. \& VICHEREK, J. 1995. Rostlinná společenstva České republiky a jejich ohrožení. Ed. 2. Severočes. Přír., Suppl. 1995: 1-206.

Mucina, L., Grabherr, G., Ellmauer, T. \& Wallnöfer, S. (eds) 1993. Die Pflanzengesellschaften Österreichs. Teil I-III. G. Fischer, Jena.

NeUHÄUSL, R. 1977. Comparative ecological study of European oak-hornbeam forests. Natur. Canad. 104: 109-117.

Potт, R. 1995. Die Pflanzengesellschaften Deutschlands. Ed. 2. Ulmer, Stuttgart. $622 \mathrm{pp}$.

Rodwell, J.S. (ed) 1990-2000. British plant communities. Vols. 1-5. Cambridge University Press, Cambridge.

ROLECEK, J. 2005. Vegetation types of dry-mesic oak forests in Slovakia. Preslia 77: 241-261.

Schaminée, J.H.J., Stortelder, A.H.F., Westhoff, V., WeEdA, E.J. \& HommeL, P.W.F.M. 1995-1999. De vegetatie van Nederland. Deel 1-5. Opulus Press, Uppsala.

Schubert, R., Hilbig, W. \& Klotz, S. 2001. Bestimmungsbuch der Pflanzengesellschaften Deutschlands. Spektrum Akademischer Verlag, Heidelberg. 472 pp.

SkALICKÝ, V. 1988. Regionálně fytogeografické členění. pp. 103121. In: HejnÝ, S. \& Slavík, B. (eds), Květena České socialistické republiky. Academia, Praha.

STUDNiČKA, M. 1980. Vegetace bílých strání Českého středohoří a dolního Poohří. Preslia, 52: 155-176.

TICHY, L. 2002. JUICE, software for vegetation classification. J. Veg. Sci. 13: 451-453.

Tichy, L., Chytrý, M., Pokorny-Strudl, M., Strudl, M. \& VichereK, J. 1997. Wenig bekannte TrockenrasenGesellschaften in den Flußtälern am Südostrand der Böhmischen Masse. Tuexenia 17: 223-237.

Toman, M. 1981. Die Gesellschaften der Klasse Festuco-Brometea im westlichen Teil des böhmischen Xerothermgebietes. Feddes Repert. 92: 303-332, 433-498 \& 569-601.

Toman, M. 1988. Beiträge zum xerothermen Vegetationskomplex Böhmens I-IV. Feddes Repert. 99: 33-80, 205-235, 339 376 \& 565-602.

Valachovič, M., OŤahelová, H., Stanová, V. \& Maglocký, Š. 1995. Rastlinné spoločenstvá Slovenska 1. Pionierska vegetácia. Veda, Bratislava.

ViCHEREK, J. \& UNAR, J. 1971. Fytocenologická charakteristika stepní vegetace jižní Moravy. Ms., research report, Institute of Botany, Průhonice.

Walter, H. \& WAlter, E. 1953. Das Gesetz der relativen Standortskonstanz; das Wesen der Pflanzengemeinschaften. Ber. Deutsch. Bot. Ges. 66: 228-236.

Westhoff, V. 1967. Problems and use of structure in the classification of vegetation. Acta Bot. Neerl. 15: 495-511.

ZlATNík, A. 1928. Études écologiques et sociologiques sur le Sesleria coerulea et le Seslerion calcariae en Tchécoslovaquie. Rozpr. Král. Čes. Společ. Nauk, cl. math.-natur., 8/1: 1-116.

Received May 18, 2005 Accepted Nov. 10, 2005 